\title{
ANALISIS KEPEMIMPINAN DAN MOTIVASI KERJA TERHADAP KINERJA KARYAWAN PADA KOPERASI KREDIT TRITUNGGAL TUKA DI DALUNG KABUPATEN BADUNG
}

\author{
I Made Jevry Dwi Suryantha', Surya Nugraha² \\ STIE Triatma Mulya, Akademi Komunitas MAPINDO \\ jevrysuryantha@yahoo.co.id ${ }^{1}$, surya.pegending@gmail.com ${ }^{2}$
}

\begin{abstract}
Abstrak
Tujuan dari penelitian ini untuk mengetahui pengaruh kepemimpinan terhadap kinerja karyawan, untuk mengetahui pengaruh motivasi kerja terhadap kinerja karyawan, untuk menganalisis dan mengidentifikasi pengaruh kepemimpinan dan motivasi kerja secara simultan terhadap kinerja karyawan Koperasi Kredit Tritunggal Tuka. Data yang digunakan dalam penelitian ini adalah data primer dan data sekunder. Data primer diperoleh oleh peneliti langsung dari penyebaran kuesioner kepada karyawan Koperasi Kredit Tritunggal Tuka. Data sekunder merupakan data yang pengumpulan dan pengolahannya diperoleh dari tempat penelitian, seperti bagan organisasi dan jumlah karyawan yang bekerja. Populasi dalam penelitian ini adalah semua karyawan Koperasi Kredit Tritunggal Tuka yang berjumlah 80 orang. Dalam penelitian ini teknik sampel yang digunakan adalah teknik sensus atau sampel jenuh. Pengolahan data dalam penelitian ini dilakukan dengan uji validitas, uji reliabilitas, uji asumsi klasik: normalitas, multikolinieritas, dan heterokedastisitas, serta analisis jalur / path analysis. Hasil penelitian ini menunjukkan bahwa bahwa Kepemimpinan (X1) dan Motivasi Kerja (X2) secara simultan berpengaruh terhadap Kinerja Karyawan (Y). Variabel Kepemimpinan secara parsial tidak berpengaruh signifikan terhadap Kinerja Karyawan. Namun variabel Motivasi Kerja secara parsial berpengaruh signifikan terhadap Kinerja Karyawan.
\end{abstract}

Kata Kunci: Kepemimpinan, Motivasi Kerja, Kinerja Karyawan

\section{PENDAHULUAN}

Pengelolaan dan pembinaan sumber daya manusia yang tepat diperlukan jika koperasi ingin bertahan dalam bisnis dan menambah daya kompetitifnya. Tetapi sejauh ini jarang sekali dilakukan pemetaan kondisi manajemen sumber daya manusia sebuah koperasi. Dalam kenyataan aspek sumber daya manusia, koperasi paling banyak disorot sebagai salah satu sumber permasalahan lemahnya keberadaan koperasi.

Tenaga kerja memiliki potensi yang besar untuk menjalakan aktivitas perusahaan. Potensi setiap sumber daya manusia yang ada dalam perusahaan harus dapat dimanfaatkan sebaik-baiknya, sehingga mampu memberikan hasil yang maksimal. Maka dari itu, kinerja karyawan perlu ditingkatkan secara optimal. Peningkatan kinerja karyawan harus dimulai dari perbaikan kemampuan kerja karyawan. Salah satu faktor yang menyebabkan meningkatnya kemampuan kerja karyawan adalah peranan seorang pemimpin dalam organisasi.

Kepemimpinan dipahami sebagai kekuatan untuk menggerakkan dan mempengaruhi orang. Kepemimpinan secara luas meliputi proses mempengaruhi dalam menentukan tujuan organisasi, memotivasi perilaku pengikut untuk mencapai tujuan, mempengaruhi untuk memperbaiki kelompok dan budayanya (Rivai, 2005).

$$
\text { Kepemimpinan }
$$

mempunyai hubungan yang sangat erat dengan motivasi karena keberhasilan seorang pemimpin dalam menggerakkan orang lain dalam mencapai tujuan yang telah ditetapkan sangat tergantung kepada kewibawaan dan sikap pemimpin dalam menciptakan motivasi kepada karyawan, maka kepemimpinan yang dibutuhkan adalah kepemimpinan yang bisa memberdayakan karyawannya. Kepemimpinan yang bisa menumbuhkan 
motivasi kerja karyawan adalah kepemimpinan yang bisa menumbuhkan rasa percaya diri para karyawan dalam menjalankan tugasnya masing-masing.

Menurut Griffin dalam Sule dan Saefullah (2006), motivasi merupakan pertimbangan yang penting bagi pemimpin karena motivasi bersama dengan kemampuan dan faktor-faktor lingkungan sangat mempengaruhi kinerja individu. Motivasi adalah dorongan yang memberikan daya perangsang kepada pegawai yang bersangkutan agar pegawai tersebut bekerja dengan segala daya dan upaya (Manullang, 2002).

Kinerja merupakan perilaku nyata yang ditampilkan setiap orang sebagai prestasi kerja yang ditampilkan oleh karyawan sesuai dengan perannya dalam perusahaan (Rivai, 2005). Untuk mencapai kinerja yang tinggi diperlukan motivasi yang kuat dari setiap karyawan. Motivasi akan mempengaruhi kinerja karyawan dalam melaksanakan tugas dan tanggung jawabnya.

Dalam melaksanakan tugas dan tanggung jawabnya diharapkan seluruh karyawan Koperasi Kredit Tritunggal Tuka mampu bekerja maksimal dengan memperhatikan instruksi dari atasan yang berkenaan dengan tugas dan tanggung jawab sesuai dengan SOP yang ada, serta dengan motivasi yang tinggi.

Kepemimpinan (leadership) adalah sifat atau karakter atau cara seseorang di dalam upaya membina dan menggerakkan seseorang atau sekelompok orang agar mereka bersedia, berkomitmen, dan setia melaksanakan tugas dan tanggung jawabnya untuk mewujudkan tujuan perusahaan yang telah ditetapkan sebelumnya (Gorda, 2006).

Motivasi adalah daya pendorong yang mengakibatkan seseorang anggota organisasi mau dan rela untuk mengerahkan kemampuan dalam bentuk keahlian atau keterampilan tenaga dan waktunya untuk menyelenggarakan berbagai kegiatan yang menjadi tanggung jawabnya dan menunaikan kewajibannya, dalam rangka pencapaian tujuan dan berbagai sasaran organisasi yang telah ditentukan sebelumnya (Siagian, 2003).
Menurut Mangkunegara (2008), kinerja sumber daya manusia adalah prestasi kerja atau hasil kerja (output) baik kualitas maupun kuantitas yang dicapai sumber daya manusia per satu periode waktu dalam melaksanakan tugas kerjanya sesuai dengan tanggung jawab yang diberikan kepadanya. Kinerja merupakan perilaku nyata yang ditampilkan setiap orang sebagai prestasi kerja yang dihasilkan oleh karyawan sesuai dengan perannya dalam perusahaan (Rivai, 2005). Kinerja seseorang merupakan ukuran sejauh mana keberhasilan seseorang dalam melakukan tugas pekerjaannya (Brahmasari \& Suprayetno, 2008).

Berkaitan dengan fenomena yang ada, dapat dilihat bahwa faktor kepemimpinan dan motivasi memiliki pengaruh terhadap kinerja setiap karyawan. Maka dari itu, penulis mengambil judul "Analisis Kepemimpinan dan Motivasi Kerja terhadap Kinerja Karyawan pada Koperasi Kredit Tritunggal Tuka Di Dalung - Kabupaten Badung".

Dari latar belakang masalah tersebut di atas, maka dapat dirumuskan masalah penelitiannya adalah sebagai berikut: (1) Apakah kepemimpinan berpengaruh terhadap kinerja karyawan Koperasi Kredit Tritunggal Tuka?, (2) Apakah motivasi kerja berpengaruh terhadap kinerja karyawan Koperasi Kredit Tritunggal Tuka?, (3) Apakah kepemimpinan dan motivasi kerja secara simultan berpengaruh terhadap kinerja karyawan Koperasi Kredit Tritunggal Tuka?

Berdasarkan rumusan masalah di atas, tujuan dari penelitian ini adalah sebagai berikut: (1) Untuk mengetahui pengaruh kepemimpinan terhadap kinerja karyawan Koperasi Kredit Tritunggal Tuka. (2) Untuk mengetahui pengaruh motivasi kerja terhadap kinerja karyawan Koperasi Kredit Tritunggal Tuka. (3) Untuk menganalisis dan mengidentifikasi pengaruh kepemimpinan dan motivasi kerja secara simultan terhadap kinerja karyawan Koperasi Kredit Tritunggal Tuka. 


\section{METODE PENELITIAN}

Tujuan dari dilakukannya penelitian ini adalah untuk menguji pengaruh kepemimpinan dan motivasi kerja terhadap kinerja karyawan di Koperasi Kredit Tritunggal Tuka di Dalung, Kabupaten Badung. Rancangan penelitian yang digunakan dalam penelitian ini adalah rancangan yang dimulai dari hipotesis sampai pada kesimpulan dan saran. Dari hipotesis yang diajukan maka dapat ditentukan variabel penelitiannya, yaitu variabel bebas dan variabel terikat. Variabel bebasnya adalah kepemimpinan dan motivasi kerja, sedangkan variabel terikatnya adalah kinerja karyawan.

Berdasarkan varibel penelitian, maka dapat ditentukan instrument penelitian dan responden yang digunakan. Langkah selanjutnya adalah mengumpulkan data dengan melakukan observasi, wawancara, dan penyebaran kuesioner. Data yang telah terkumpul kemudian diolah dan dianalisis.Data yang telah diolah dibahas dan diiterpretasikan. Dari pembahasan dan interpretasi hasil penelitian, barulah kemudian disimpulkan dan diberikan saran.

Populasi dalam penelitian ini adalah semua karyawan Koperasi Kredit Tritunggal Tuka yang berjumlah 80 orang. Terbatasnya jumlah populasi dalam penelitian ini maka teknik sampel yang digunakan adalah teknik sensus atau sampel jenuh.

Berdasarkan pokok masalah dan hipotesis yang diajukan, variabel-variabel dalam analisis ini dapat diidentifikasikan sebagai berikut:

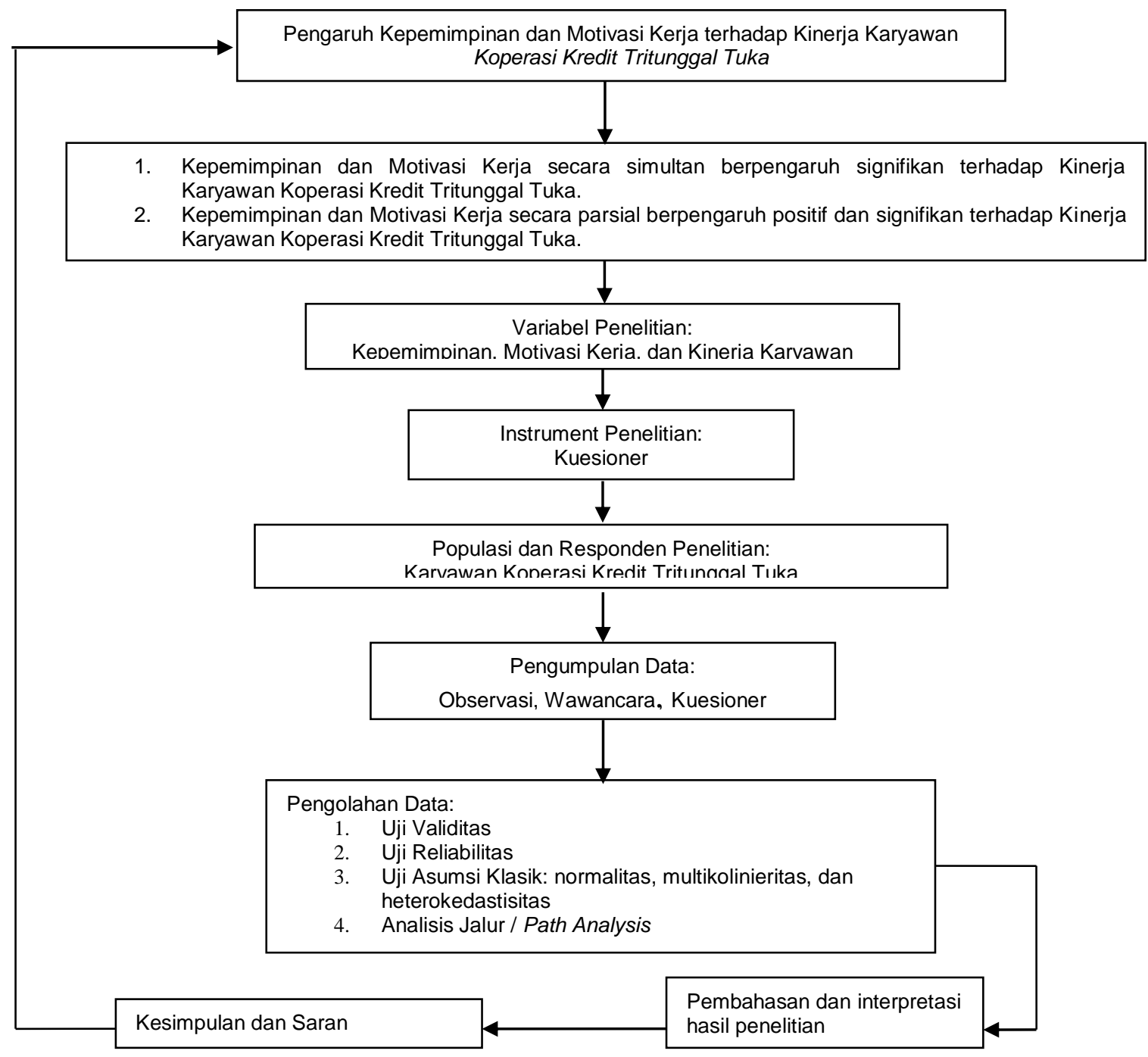

Gambar 1. Rancangan Penelitian 
Dalam penelitian ini variabel bebas (Independent Variabel) sebagai berikut: Kepemimpinan yang diukur dengan indikator variabel, yaitu: bersifat adil, memberi sugesti, mendukung tujuan, katalisator, menciptakan rasa aman, sebagai wakil organisasi, sumber inspirasi, bersikap menghargai. Selain itu, motivasi kerja yang diukur dengan indikator variabel, adalah: hubungan dengan rekan kerja dan atasan, lingkungan kerja, kesempatan meningkatkan pengetahuan dan keterampilan, pemberian tunjangan.

Dalam penelitian ini variabel terikat (Dependent Variabel) : kinerja karyawan yang diukur dengan indicator variabel, yaitu: kuantitas, kualitas, ketepatan waktu, kehadiran, kemampuan bekerjasama.

Adapun definisi operasional yang dimaksud untuk variabel-variabel dalam penelitian ini adalah sebagai berikut:

Yang pertama, Kepemimpinan (X1) adalah kemampuan pimpinan untuk mempengaruhi karyawan menuju tercapainya tujuan organisasi Koperasi Kredit Tritunggal Tuka. Kedua, Motivasi Kerja (X2) adalah semangat kerja yang terdapat dalam diri karyawan yang mampu menggerakkan segala kemampuan yang dimiliki untuk mencapai suatu tujuan yang diharapkan Koperasi Kredit Tritunggal Tuka. Dan yang ketiga, Kinerja Karyawan adalah kemampuan karyawan Koperasi Kredit Tritunggal Tuka untuk melaksanakan tugas-tugas dan pekerjaan dengan potensi diri yang dimiliki. bekerjasama.

Setiap butir/item pertanyaan yang dijabarkan dari indikator masing-masing variabel menggunakan Skala Linkert 5 titik dari skor 1 (sangat tidak setuju - SST) sampai dengan 5 (sangat setuju - SS).

Berdasarkan uraian definisi operasional di atas, maka dapat disajikan secara ringkas indikator dan item pertanyaan dari masing-masing variabel penelitian pada tabel berikut ini:

Tabel 1. Variabel Operasional dan Indikator Penelitian

\begin{tabular}{|c|c|c|}
\hline Variabel & Indikator Penelitian & Item/Butir-Butir Penelitian \\
\hline $\begin{array}{l}\text { Kepemimpinan } \\
\text { (X1) }\end{array}$ & $\begin{array}{l}\text { 1. } \text { Bersifat adil } \\
\text { 2. Memberikan sugesti } \\
\text { 3. Mendukung tercapainya tujuan } \\
\text { 4. Sebagai katalisator } \\
\text { 5. Menciptakan rasa aman } \\
\text { 6. Sebagai wakil organisasi } \\
\text { 7. Sumber inspirasi } \\
\text { 8. } \\
\text { Bersikap menghargai }\end{array}$ & $\begin{array}{l}\text { 1. Pemimpin bertindak adil kepada } \\
\text { seluruh karyawan } \\
\text { 2. Pemimpin mampu mengkoordinir } \\
\text { karyawan } \\
\text { 3. Pemimpin bekerjasama dengan } \\
\text { karyawan dalam mencapai tujuan } \\
\text { 4. Pemimpin mampu meningkatkan } \\
\text { kinerja karyawan } \\
\text { 5. Pemimpin menjamin keamanan } \\
\text { karyawan dalam bekerja } \\
\text { 6. Pemimpin mempunyai peran } \\
\text { dalam segala bidang kegiatan } \\
\text { 7. Pemimpin mampu meningkatkan } \\
\text { semangat kerja karyawan } \\
\text { 8. Pemimpin memberikan } \\
\text { penghargaan kepada bawahannya } \\
\text { yang berprestasi }\end{array}$ \\
\hline Variabel & Indikator Penelitian & Item/Butir-Butir Penelitian \\
\hline Motivasi Kerja (X2) & $\begin{array}{l}\text { 1. Hubungan dengan rekan kerja } \\
\text { dan atasan } \\
\text { 2. Lingkungan kerja } \\
\text { 3. Kesempatan meningkatkan } \\
\text { pengetahuan dan keterampilan } \\
\text { 4. Pemberian tunjangan }\end{array}$ & $\begin{array}{l}\text { 1. Suasana harmonis terjalin di } \\
\text { tempat kerja } \\
\text { 2. Terdapat fasilitas penunjang } \\
\text { pekerjaan yang memadai } \\
\text { 3. Perusahaan selalu memberikan } \\
\text { pendidikan dan pelatihan bagi } \\
\text { karyawan } \\
\text { 4. Perusahaan telah memberikan } \\
\text { tunjangan yang layak bagi } \\
\text { karyawan }\end{array}$ \\
\hline Kinerja Karyawan (Y1) & $\begin{array}{l}\text { 1. Kuantitas } \\
\text { 2. Kualitas }\end{array}$ & $\begin{array}{l}\text { 1. Penyelesaian pekerjaan melebihi } \\
\text { target }\end{array}$ \\
\hline
\end{tabular}




\begin{tabular}{|c|c|c|}
\hline & $\begin{array}{ll}\text { 3. } & \text { Ketepatan waktu } \\
\text { 4. } & \text { Kehadiran } \\
\text { 5. } & \text { Kemampuan bekerjasama }\end{array}$ & $\begin{array}{l}\text { 2. Kualitas penyelesaian pekerjaan } \\
\text { 3. Tepat waktu dalam menyelesaikan } \\
\text { pekerjaan } \\
\text { 4. Karyawan hadir di tempat tepat } \\
\text { waktu sesuai jam kerja } \\
\text { 5. Karyawan mampu bekerjasama } \\
\text { dalam menyelesaikan pekeriaan }\end{array}$ \\
\hline
\end{tabular}

Sumber: Wahjosumidjo, 1991

Data yang digunakan dalam penelitian ini adalah data primer dan data sekunder. Data primer diperoleh oleh peneliti langsung dari penyebaran kuesioner kepada karyawan Koperasi Kredit Tritunggal Tuka. Data sekunder merupakan data yang pengumpulan dan pengolahannya diperoleh dari tempat penelitian, seperti bagan organisasi dan jumlah karyawan yang bekerja.

Metode pengumpulan data dilakukan dengan 3 cara, yaitu:

1. Observasi

Observasi yaitu teknik pengumpulan data dengan cara melakukan pengamatan secara langsung terhadap kegiatan dalam perusahaan.

2. Wawancara

Wawancara merupakan teknik pengumpulan data dalam metode survei yang menggunakan pertanyaan secara lisan kepada subyek penelitian. Wawancara dilakukan untuk pengumpulan data primer (riil sesuai dengan obyek), yaitu: absensi dan output, data sekunder berupa data nasabah dan laporan keuangan, serta data pendamping lainnya.

3. Kuesioner

Kuesioner merupakan teknik pengumpulan data dengan cara membuat daftar pertanyaan secara tertulis yang ditujukan kepada subyek penelitian untuk diisi. Kuesioner dibuat dengan disertai tempat untuk menjawab pertanyaan tersebut. Kuesioner yang didistribusikan kepada karyawan Koperasi Kredit Tritunggal Tuka berupa kuesioner tertutup yang menggunakan Skala Linkert 1-5 dimana 1 menunjukkan tingkatan sangat tidak setuju, sedangkan tingkatan 5 menunjukkan sangat setuju.

Instrumen penelitian (kuesioner) merupakan metode pengumpulan data yang utama dalam penelitian ini untuk memperoleh data yang memiliki kalibrasi yang baik untuk masing-masing ukuran variabel yang diteliti, maka instrumen penelitian perlu diuji validitas dan reliabilitasnya.

Pengujian validitas dan reliabilitas terhadap instrumen-instrumen di dalam kuesioner sangatlah penting dilakukan untuk memperoleh hasil penelitian yang valid dan reliabel. Suatu instrumen dikatakan valid apabila mampu mengukur apa yang ingin diukur dan dapat mengungkapkan data dari variabelvariabel secara tetap. Ketentuan instrumen dikatakan valid apabila memiliki koefisian Pearson Product Moment $(r)>$ 0,30 dengan $(\alpha)$ sebesar 0,05 . Sedangkan reliabel atau handal merupakan indeks yang menunjukkan sejauh mana suatu alat ukur dapat dipercaya atau dapat diandalkan untuk mengukur berbagai aspek dari suatu variabel penelitian. Menurut Arikunto (2002), suatu intrumen dikatakan reliabel atau handal apabila memiliki koefisien reliabilitas ( $\alpha$ ) sebesar 0,60 atau lebih.

Analisis data dalam penelitian ini menggunakan metode analisis deskriptif yaitu memberikan gambar mengenai demografi responden penelitian (jenis kelamin, tingkat usia, masa kerja, dan pendidikan terakhir), serta deskripsi mengenai variabel-variabel penelitian. Analisis deskriptif terhadap demografi responden penelitian dilakukan dengan pemberian angka baik dalam jumlah maupun persentase, sedangkan deskripsi variabel-variabel penelitian dilakukan untuk mengetahui gambaran persepsi responden terhadap pertanyaan yang diberikan dalam instrumen penelitian tentang variabel-variabel yang diteliti. Rerata (mean) yang digunakan dalam analisis ini untuk mengetahui sebaran dari tanggapan responden terhadap 
pertanyaan-pertanyaan dalam instrumen penelitian yang digunakan.

Teknik analisis inferensial digunakan untuk melihat pengaruh diantara varibelvariabel yang tengah diteliti. Untuk tujuan analisis data dan pengujian hipotesis digunakan taraf signifikansi sebesar 5\%. Agar sesuai dengan tujuan penelitian, analisis data dilakukan secara kuantiatif untuk menjelaskan dan mendeskripsikan hubungan variabel yang diteliti dengan landasan teori yang dipakai melalui uraian yang sistematik. Untuk analisis statistik diferensial dilakukan uji hipotesis penelitian dengan menggunakan analisis jalur (Path Analysis).

Sebelum melakukan analisis jalur untuk menguji hipotesis yang diajukan, maka model penelitian yang dihasilkan dari perhitungan regresi melalui bantuan SPSS, harus dilakukan evaluasi ekonometrik (uji analisis klasik) agar model penelitian benar-benar menggambarkan fenomena kausal dan korelasional antar variabel yang diteliti, pengujian ini meliputi: uji normalitas, multikolinearitas, dan heteroskedastisitas yang nantinya diolah menggunakan program SPSS 17.0 for windows.

a. Uji Normalitas

Uji normalitas data merupakan pengujian data yang bertujuan untuk mengetahui distribusi data mendekati distribusi normal. Pengujian normalitas data pada penelitian ini menggunakan pendekatan uji sampel Kolmogorov Smirnov dengan kriteria: jika $\mathrm{p}>0,05$ sebaran datanya berdistribusi normal dan sebaliknya jika $p<0,05$ sebaran datanya tidak normal.

b. Uji Multikolinearitas

Uji multikolinearitas dipergunakan untuk mengetahui adanya hubungan linear antar variabel independen dalam model regresi. Pada penelitian ini, uji multikolinearitas dilakukan dengan melihat nilai inflation factor (VIF) pada model regresi. Jika VIF > 5 maka variabel tersebut mempunyai persoalan multikolinearitas dengan variabel bebas lainnya. c. Uji Heteroskedastisitas

Uji heteroskedastisitas digunakan untuk mengetahui adanya ketidaksamaan varian dari residual untuk semua pengamatan pada model regresi. Prasyarat yang harus terpenuhi dalam model regresi adalah tidak adanya gejala heteroskedastisitas. Pada penelitian ini akan dilakukan uji heteroskedastisitas dengan mengamati pola tertentu pada grafik Scatterplot antara SRESID dengan ZPRED dimana sumbu yang telah diprediksi dan sumbu $X$ adalah residual.

Dalam penelitian ini, analisis jalur digunakan untuk menganalisis data yang diperoleh karena dari model yang disusun terdapat keterkaitan hubungan antara sejumlah variabel yang dapat diestimasi secara simultan. Variabel dependen pada sutu hubungan yang sudah ada akan manjadi variabel independen pada hubungan selanjutnya. Menurut Solimun (2008), dalam analisis jalur terdapat beberapa langkah sebagai berikut:

1. Merancang model berdasarkan konsep dari teori

Analisis jalur merupakan pengembangan lebih lanjut dari analisis regresi berganda dan bivariate. Analisis jalur ingin menguji persamaan regresi yang melibatkan beberapa variabel exogendanendogen sekaligus sehingga memungkinkan pengujian terhadap variabel mediating/intervening atau variabel antara. Analisis jalur juga dapat mengukur hubungan langsung antara variabel maupun hubungan tidak langsung antar variabel dalam model. Berikut model persamaan regresinya:

Kinerja Karyawan $=\beta 0+\beta 1$ Kepemimpinan $+\beta 2$ Motivasi kerja + e1

2. Pemeriksaan terhadap asumsi yang melandasi.

Asumsi yang melandasi analisis path dalam penelitian ini adalah:

a. Di dalam model analisis path, hubungan antar variabel adalah linier dan aditif. 
b. Hanya rekursif yang dapat dipertimbangkan, yaitu hanya sistem aliran causal ke satu arah, sedangkan pada model yang mengandung causal resiprokal, analisis tidak dapat dilakukan.

c. Variabel endogen minimal dalam skala ukur interval.

d. Observed variables diukur tanpa kesalahan (instrument pengukuran valid dan reliable).

e. Model yang dianalisis dispesifikasikan (diidentifikasikan) dengan benar berdasarkan teoriteori dan konsep-konsep yang relevan.

3. Pendugaan parameter atau perhitungan koefisien path.

4. Pemeriksaan validitas model.

Sahih tidaknya suatu hasil bergantung pada terpenuhi atau tidaknya asumsi yang melandasinya. Asumsi yang melandasi analisis path dalam penelitian ini adalah:

a. Di dalam model analisis path, hubungan antar variabel adalah linier dan aditif.

b. Hanya rekursif yang dapat dipertimbangkan, yaitu hanya sistem aliran causal ke satu arah, sedangkan pada model yang mengandung causal resiprokal, analisis tidak dapat dilakukan.

c. Variabel endogen minimal dalam skala ukur interval.

d. Observed variables diukur tanpa kesalahan (instrument pengukuran valid dan reliable).

e. Model yang dianalisis dispesifikasikan (diidentifikasikan) dengan benar berdasarkan teoriteori dan konsep-konsep yang relevan. Dalam penelitian ini uji validitas akan menggunakan program SPSS.

5. Melakukan interpretasi hasil analisis temuan penelitian, serta mencari implikasi teoritiknya.

\section{HASIL DAN PEMBAHASAN Uji Validitas}

Nilai $r$ tabel dengan $N=80$ pada signifikansi $5 \%$ ditemukan nilai $r$ tabel sebesar 0,220. Berdasarkan rekapitulasi hasil perhitungan nilai $r$ hitung dari tiaptiap item pertanyaan pada tabel 6.5 diperoleh hasil yang besarnya di atas 0,220 . Hal ini menyatakan bahwa semua item pertanyaan dalam kuesioner tersebut dapat dikatakan valid dan bisa dijadikan sebagai alat pengumpul data dalam penelitian ini.

\section{Uji Reliabilitas}

Berdasarkan rekapitulasi hasil perhitungan diketahui bahwa nilai alpha sebesar 0,850 sedangkan nilai $r$ tabel dengan nilai $\mathrm{N}=80$ pada distribusi nilai $r$ tabel signifikansi $5 \%$ diperoleh nilai sebesar 0,220 . Dengan alpha $=0,850>r$ tabel $=0,220$ maka item-item pada angket penelitian dapat dikatakan reliabel atau terpercaya sebagai alat pengumpul data dalam penelitian.

\section{Keterkaitan antara Kepemimpinan dengan Kinerja Karyawan}

Untuk mengetahui secara lebih rinci pengaruh Kepemimpinan (X1) terhadap Kinerja Karyawan ( $Y$ ) di Koperasi Kredit Tritunggal Tuka maka dapat dilihat dari hasil perhitungan yang menunjukkan taraf signifikansi sebesar 0,601>0,05 sehingga dapat disimpulkan bahwa kepemimpinan tidak memiliki pengaruh positif dan signifikan terhadap kinerja karyawan. Kepemimpinan juga memiliki pengaruh tidak langsung terhadap kinerja karyawan di Koperasi Kredit Tritunggal Tuka.

Secara parsial kepemimpinan tidak memiliki pengaruh positif dan signifikan terhadap kinerja karyawan di Koperasi Kredit Tritunggal Tuka.

\section{Keterkaitan antara Motivasi Kerja terhadap Kinerja Karyawan}

Untuk mengetahui secara lebih rinci pengaruh Motivasi Kerja (X2) terhadap Kinerja Karyawan (Y) di Koperasi Kredit Tritunggal Tuka maka dapat dilihat dari hasil perhitungan yang menunjukkan taraf signifikansi sebesar 0,003 $<0,05$ sehingga dapat disimpulkan bahwa motivasi kerja memiliki pengaruh positif dan signifikan terhadap kinerja karyawan. Motivasi kerja juga memiliki pengaruh langsung terhadap kinerja karyawan di Koperasi Kredit Tritunggal Tuka. 
Secara parsial motivasi kerja memiliki pengaruh positif dan signifikan terhadap kinerja karyawan di Koperasi Kredit Tritunggal Tuka.

\section{Keterkaitan antara Kepemimpinan dan Motivasi Kerja terhadap Kinerja Karyawan}

Secara simultan nilai signifikansi $0,000<0,05$ sesuai dengan dasar pengambilan keputusan dalam uji $\mathrm{F}$ maka dapat disimpulkan bahwa Kepemimpinan (X1) dan Motivasi Kerja (X2) secara simultan berpengaruh terhadap Kinerja Karyawan (Y). Sedangkan secara parsial berdasarkan hasil output di atas, nilai $t$ hitung variabel $\mathrm{X} 1$ lebih kecil dari pada nilai t tabel $(0,525<1,994)$ dengan tingkat signifikansi di atas 0,05 yaitu 0,601 dan $t$ hitung variabel $\mathrm{X} 2$ lebih besar dari pada $t$ tabel $(3,032>1,994)$ dengan tingkat signifikansi di bawah 0,05 yaitu 0,003 Berdasarkan hal tersebut maka dapat disimpulkan bahwa:

1. Variabel Kepemimpinan secara parsial tidak berpengaruh signifikan terhadap Kinerja Karyawan.

2. Variabel Motivasi Kerja secara parsial berpengaruh signifikan terhadap Kinerja Karyawan.

\section{KESIMPULAN DAN SARAN}

Dapat disimpulkan bahwa, keterkaitan antara kepemimpinan dengan kinerja karyawan di Koperasi Kredit Tritunggal Tuka, Dalung, Kabupaten Badung dapat dipandang bahwa: (1) Kepemimpinan dinilai tidak mampu meningkatkan kinerja karyawan, (2) Rendahnya tingkat kedisiplinan karyawan untuk selalu hadir tepat waktu sesuai dengan jam kerja yang telah ditetapkan.

Keterkaitan antara Motivasi Kerja dengan Kinerja Karyawan Koperasi Kredit Tritunggal Tuka, Dalung, Kabupaten Badung dapat dilihat dari motivasi kerja yang semakin kuat mampu meningkatkan kinerja karyawan Penguatan motivasi kerja didorong melalui perusahaan yang memberikan pendidikan dan pelatihan bagi karyawan, selain itu juga dilihat dari tingginya tingkat kinerja karyawan Koperasi Kredit Tritunggal Tuka di Dalung,
Kabupaten Badung didukung oleh karyawan yang mampu bekerja sama dalam menyelesaikan pekerjaan.

Berdasarkan bukti empiris yang diperoleh dengan sejumlah keterbatasan dalam penelitian ini, selanjutnya diusulkan beberapa saran yang mungkin dapat dilakukan dan bermanfaat bagi peningkatan kinerja karyawan Koperasi Kredit Tritunggal Tuka di Dalung, Kabupaten Badung. Adapun saran yang diusulkan sebagai berikut: Kepemimpinan kurang memiliki peran dalam meningkatkan kinerja karyawan di Koperasi Kredit Tritunggal Tuka di Dalung, Kabupaten Badung. Dikarenakan kepemimpinan digunakan sebagai dasar atau acuan kualitas dari manajemen itu sendiri, maka untuk meningkatkan kualitas kepemimpinan di Koperasi Kredit Tritunggal Tuka di Dalung, Kabupaten Badung, pemimpin perlu memperhatikan beberapa hal berikut ini: (a) Pimpinan selalu bertindak adil terhadap seluruh bawahannya. (b) Pimpinan mampu mengkoordinir karyawan. (c) Pimpinan ikut serta meningkatkan kinerja karyawan. (d) Pimpinan menciptakan rasa aman bagi para bawahannya. (e) Pimpinan ikut berperan serta dalam segala bidang kegiatan. (f) Pimpinan menjadi sumber semangat bagi para bawahannya. (g) Pimpinan memberikan penghargaan kepada bawahannya yang berprestasi. Semua upaya-upaya di atas diharapkan bisa meningkatkan kinerja karyawan di Koperasi Kredit Tritunggal Tuka di Dalung, Kabupaten Badung.

Motivasi kerja memiliki peranan penting dalam meningkatkan kinerja karyawan. Oleh karena itu, pimpinan manajemen Koperasi Kredit Tritunggal Tuka di Dalung, Kabupaten Badung harus memberikan perhatian dan dorongan kepada seluruh karyawan agar mereka termotivasi dalam bekerja, antara lain dengan: (a) Meningkatkan suasana harmonis antar karyawan di tempat kerja. (b) Meningkatkan fasilitas penunjang pekerjaan yang memadai. (c) Memberikan tunjangan yang layak bagi karyawan. Semua upaya-upaya di atas diharapkan bisa meningkatkan kinerja karyawan di 
Koperasi Kredit Tritunggal Tuka di Dalung, Kabupaten Badung.

Untuk mencapai tujuan yang telah ditetapkan maka diharapkan kepada seluruh karyawan yang tergabung dalam manajemen Koperasi Kredit Tritunggal Tuka di Dalung, Kabupaten Badung, untuk melakukan beberapa hal berikut ini, yaitu: (a) Menyelesaikan pekerjaan melebihi target yang telah ditentukan. (b) Hasil pekerjaan memiliki kualitas penyelesaian yang memuaskan. (c) Mampu menyelesaikan pekerjaan tepat waktu. (d) Selalu hadir tepat waktu sesuai dengan jam kerja. Semua upaya-upaya di atas diharapkan bisa meningkatkan kinerja karyawan di Koperasi Kredit Tritunggal Tuka di Dalung, Kabupaten Badung.

\section{DAFTAR PUSTAKA}

Arikunto, S. 2002. Pengaruh Penelitian Pendekatan Praktik. Jakarta: Rineka Cipta.

Brahmasari, Suprayetno. 2008. Pengaruh Motivasi Kerja, Kepemimpinan, dan Budaya Organisasi Terhadap Kepuasan Kerja. (Studi kasus pada. PT. Pei Hei International Wiratama Indonesia)

Gorda, I Gusti Ngurah. 2006. Manajemen Sumber Daya Mausia. Denpasar: Astabrata Bali Denpasar bekerjasama dengan STIE Satya Dharma Singaraja.

Malthis, Robert. L, John H. Jackson. 2006. Human Resource Manajemen. Jakarta: Salemba Empat

Manullang. 2002. Manajemen Sumber daya Manusia. PT. Gramedia.

Rivai. 2005. Manajemen Sumber Daya Manusia dan Kunci Keberhasilan. Edisi Revisi, Jakarta: Bumi Aksara.

Slamet, Achmad. 2007. Manajemen Sumber Daya Manusia. Semarang: Unnes Press.

Siagian, Sondang P. 2003. Manajemen Sumber Daya Manusia. Jakarta: Bumi Aksara

Sugiyono.2007. Statistika untuk Penelitian. Bandung: Alfabeta.

Sule, Erni Trisnawati dan Kurniawan Saefullah. 2006. Pengantar Manajemen. Jakarta : Kencana
Solimun. 2008. Memahami Metode Kuantitatif Mutakhir Structural Equation Modeling dan Partial Least Square. Malang. Program Studi Statistika FMIPA Universitas Brawijaya.

Wahjosumidjo. 1991. Kepemimpinan yang Efektif. Yogyakarta: Balai Pustaka. 